\title{
Dynamics in the length-weight parameters of the mudskipper Periophthalmus barbarus (Gobiidae), in Imo River estuary, Nigeria
}

\author{
Richard P. King \& Mfon T. Udo \\ Department of Zoology, University of Uyo; PMB 1017, Uyo, Akwa Ibom State, Nigeria
}

\begin{abstract}
Seasonal and intersexual dynamics in parameters of the length-weight relationship of the mudskipper Periophthalmus barbarus, from Imo River estuary, Nigeria, were studied. The proportionality constant or intercept (a) was aseasonal in males, but in females it was significantly higher in the dry season (November-April) than during the rains (May-October) due to heightened breeding activity. The length exponent (b) depicted seasonal isometry in males. In females, isometry was evident in the dry season while a positive allometry occurred during the wet season. The sizes of the smallest and largest specimens examined did not regulate variations in the magnitudes of (a) and (b) in both sexes. The insignificant intersexual variation in the length-weight parameters suggests the possibility of using a single predictive length-weight equation for the population. However, the sexes exhibited different monthly rank-orders of (a) and (b), thus making such composite estimates unreliable for a study spanning up to a year. Values of (a) and (b) were inversely correlated in both sexes. The population dynamics implications of the results are discussed.
\end{abstract}

\section{INTRODUCTION}

Fish body weight is a function of any of its linear dimensions e.g. length. The lengthweight relationship (LWR) of a fish population provides a means of interpreting measures of length and weight at any give life stage. The LWR of a fish species describes the functional regime in weight distribution per unit size of a subpopulation, a vital attribute for analysing population dynamics.

The parameters of the functional length-weight (LW) equation are required for a number of practical applications including, inter alia, the rapid conversion of the length of an individual fish to weight in assessing total biomass or standing stock; estimating the mean weight of the fish of a given length class; assessment of population biomass yield model of Berverton-Holt (Tyler \& Gallucci, 1980); the conversion of length-specific von Bertalanffy growth model to the weight-specific growth model (Royce, 1972); the evaluation of overall weight growth performance index (Moreau et al., 1986) and interpopulational comparison of the gross morphology of the same species or between different species.

The LWR of a fish species is typical of a given habitat and is indicative of the adequacy of the complex of synecological conditions that influence fish growth and development in that environment (Becker, 1972). It is thus logical to assume that the parameters of the LWR - regression intercept (a), length exponent (b) - of a given species may 
vary seasonally in response to fluctuating environmental conditions and biological phenomena such as reproductive investment and spawning. However, most records of the LWRs of Nigerian fishes, and indeed those of fishes from other regions, are largely based on the overall trends. Consequently, there is a dearth of information on the seasonal and intersexual dynamics of the LWR of fishes.

The present contribution examines the temporal (monthly and seasonal) and intersexual dynamics in the parameters of the LWR of the mudskipper Periophthalmus barbarus, in Imo River estuary, Nigeria (Fig.1). Very little is known about the biology of this amphibious fish in spite of its role in supporting subsistence/artisanal fisheries as well as its status as an endangered species (Egborge, 1993).

The Imo River basin is located in the tropical rainforest belt with an equatorial climatic regime typified by the dry (November-April) and wet (May-October) seasons. Detailed description of the hydrometeorological conditions in the study area are contained in Enplan group (1974).

\section{MATERIALS AND METHODS}

Monthly samples of Periophthalmus barbarus were obtained from the intertidal saline swamp of Imo River estuary at Ikot Abasi (Fig.1) between April, 1993 and March, 1994, using unbaited conical valved basket traps. Each specimen was sexed by means of the genital papilla (being larger in females than males), measured (total length, $\mathrm{cm}$ ) and weighed (total weight, $g$ ) after draining excess water from buccal cavity and blot-drying the body.

The LWR was based on an empirical allometric equation of the form (Tyler \& Gallucci, 1980):

$$
W=a \cdot L^{b}
$$

where $\mathrm{W}=$ total weight, $\mathrm{L}=$ total length, $\mathrm{a}=$ proportionality constant and $\mathrm{b}=$ regression exponent. The LW parameters $(a, b)$ were estimated by regressing (least squares regression technique) weight on length using base-10 double log-transformation of the data pairs:

$$
\log W=a+b \log L
$$

The following relationships were also evaluated using least squares regression method with base-10 log transformation of data pairs: $a v s$ b; a vs minimum length $\left(\mathrm{L}_{\min }\right)$; $\mathrm{b}$ vs $\mathrm{L}_{\min }$ a vs maximum length ( $\mathrm{L}_{\max }$ ); $\mathrm{b}$ vs $\mathrm{L}_{\max }$. Variabilities in values of $\mathrm{a}$ and $\mathrm{b}$ were analysed by the coefficient of variation (CV) and associated F-ratio test (Lewontin, 1966).

\section{RESULTS}

Table 1 presents the monthly variations in the parameters of the LWRs of male Periophthalmus barbarus, along with the sample sizes, size limits and correlation coefficients. Annual mean proportionality constant was $a=0.0119=0.0057$ with high variability $(\mathrm{CV}=47.9 \%)$. It ranged from 0.0065 in May and November to 0.0251 in March. The dry and wet season (a) values were not significantly different $(t=0.710, d f=10, p>0.05)$; intraseason variability was slightly higher in the dry than in the wet season even though this difference was not statistically significant $(F=2.459, p>0.05$ : Table 2$)$. 


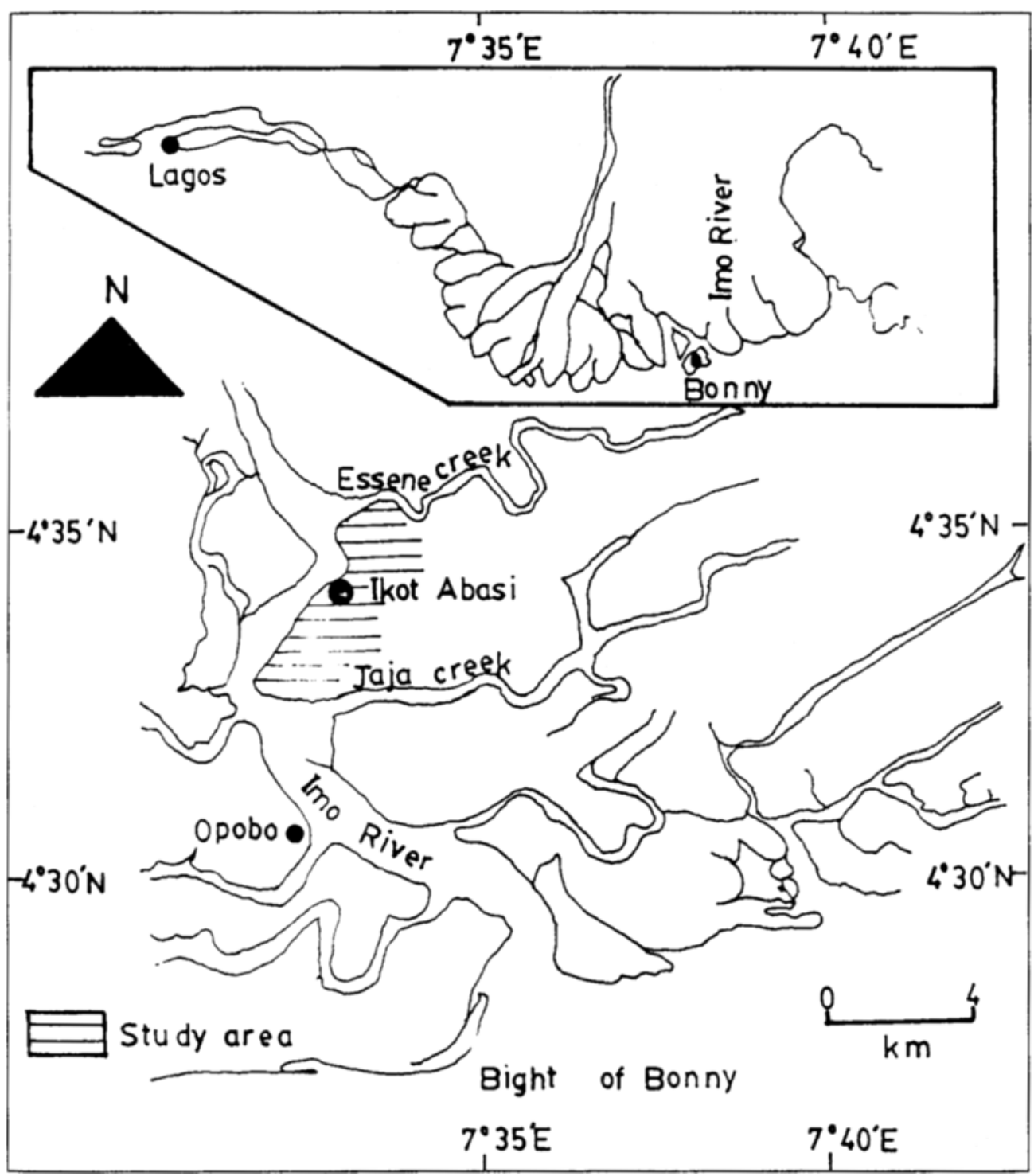

Fig 1. Map of Ino River estuary, showing the location of the study area. Inset: Map of Nigeria, showing the location of Imo River 
Table 1. Monthly variation in the parameters of the length-weight relationship of male $P$. barbarus in Imo River estuary, Nigeria

\begin{tabular}{|c|c|c|c|c|c|c|}
\hline \multirow[t]{2}{*}{ Months } & \multirow[t]{2}{*}{$\mathrm{N}$} & \multicolumn{2}{|c|}{ Total length $(\mathrm{cm})$} & \multicolumn{2}{|c|}{ Regression parameters } & \multirow[t]{2}{*}{$\mathrm{r}^{*}$} \\
\hline & & $\mathrm{L}_{\min }$ & $\mathrm{L}_{\max }$ & Intercept (a) & Exponent (b) & \\
\hline April & 42 & 5.4 & 10.7 & 0.0089 & 3.077 & 0.982 \\
\hline May & 30 & 6.3 & 10.6 & 0.0065 & 3.230 & 0.979 \\
\hline June & 39 & 5.7 & 11.6 & 0.0066 & 2.224 & 0.987 \\
\hline July & 35 & 6.1 & 13.7 & 0.0125 & 2.974 & 0.990 \\
\hline August & 36 & 7.5 & 15.6 & 0.0103 & 3.027 & 0.986 \\
\hline September & 52 & 3.3 & 12.1 & 0.0093 & 3.076 & 0.994 \\
\hline October & 33 & 5.9 & 11.6 & 0.0181 & 2.729 & 0.924 \\
\hline November & 32 & 4.6 & 11.2 & 0.0065 & 3.211 & 0.923 \\
\hline December & 33 & 6.3 & 14.3 & 0.0084 & 3.091 & 0.991 \\
\hline January & 36 & 5.5 & 14.0 & 0.0160 & 2.885 & 0.985 \\
\hline February & 37 & 5.3 & 12.9 & 0.0143 & 2.918 & 0.981 \\
\hline March & 50 & 6.3 & 10.6 & 0.0251 & 2.676 & 0.910 \\
\hline
\end{tabular}

Overall mean length exponent was $b=3.010 \pm 0.183$ with low variability $(\mathrm{CV}=6.1 \%)$. The (b) was not significantly different from the cubic value ( $t=0.200, d f=11, p>0.1$ ). Table 2 shows the seasonal (b) values; mean (b) was not significantly different from 3.0 in both the dry $(t=0.309, \mathrm{df}=11, \mathrm{p}>0.1)$ and wet $(\mathrm{t}=0.566, \mathrm{df}=11, \mathrm{p}>0.1)$ seasons. The dry and wet season mean values of (b) were not significantly different from each other $(\mathrm{t}=0.564, \mathrm{df}=10, \mathrm{p}>0.1$ ); intraseason variabilities were low and not significantly different from each other $(F=1.044, p>0.05)$.

Throughout the year, values of (a) and (b) were strongly inversely correlated $(\mathrm{r}=-0.987, \mathrm{df}=10, \mathrm{p}<0.001$ : Table 1$)$ according to the power function:

$$
a=24.3729(b)^{-7.016}
$$

which accounted for $97.4 \%$ of the variance $\left(\mathrm{r}^{2}\right)$ in the data. There were no significant correlations in the following relationships: $\mathrm{L}_{\min } v s(\mathrm{a})(\mathrm{r}=0.193, \mathrm{df}=10, \mathrm{p}>0.1), \mathrm{L}_{\min }$ vs (b) $(\mathrm{r}=-0.204, \mathrm{df}=10, \mathrm{p}>0.1), \mathrm{L}_{\max }$ vs $(\mathrm{a})(\mathrm{r}=0.089, \mathrm{df}=10, \mathrm{p}>0.1)$ and $\mathrm{L}_{\max }$ vs $(\mathrm{b})$ $(\mathrm{r}=-0.041, \mathrm{df}=10, \mathrm{p}>0.1)$. The composite $\mathrm{LW}$ function for male $P$. barbarus was $(\mathrm{r}=0.990, \mathrm{df}=453, \mathrm{p}<0.001)$ :

$$
W=0.0093 L^{3.084}
$$

This shows that weight increased isometrically with fish length; about $98.0 \%$ of the variation in body weight was explained by changes in length.

The monthly trends in the LW parameters of female $P$. barbarus, along with the sample sizes and size ranges are presented in Table 3 . Overall mean proportionality constant was $\mathrm{a}=0.0101 \pm 0.0031$ with a moderately high variability $(\mathrm{CV}=30.7 \%)_{\text {; }}$ mean value of (a) was significantly higher in the dry season than during the rains $(t=3.447, \mathrm{df}=10$, $p<0.01$ ) (Table 2 ) but intraseason variabilities were not significantly different $(F=1.633$, $\mathrm{p}>0.05)$. 
Table 2 . Seasonal variation in the parameters of the length-weight relationship of male and female $P$. barbarus in Imo River estuary, Nigeria

\begin{tabular}{|lllll|}
\hline Length-weight parameters & \multicolumn{3}{c}{ Seasons } & \\
& Dry season & $(\mathrm{N})$ & Wet season & $(\mathrm{N})$ \\
\hline Males & & & & \\
$\quad$ Intercept $(\mathrm{a} \pm \mathrm{sd})$ & $0.0132 \pm 0.0069$ & $(6)$ & $0.0106 \pm 0.0044$ & $(6)$ \\
$\quad$ Coefficient of variation (\%) & 52.3 & & 41.5 & \\
Exponent $(\mathrm{b} \pm \mathrm{sd})$ & $2.97 \pm 0.0190$ & $(6)$ & $3.043 \pm 0.186$ & $(6)$ \\
Coefficient of variation (\%) & 6.4 & & 6.1 & \\
Females & & & & \\
Intercept $(\mathrm{a} \pm \mathrm{sd})$ & $0.012 \pm 0.0023$ & $(6)$ & $0.0079 \pm 0.0018$ & $(6)$ \\
Coefficient of variation (\%) & 1.86 & & 22.8 & \\
Exponent $(\mathrm{b} \pm$ sd) & $2.948 \pm 0.079$ & $(6)$ & $3.154 \pm 0.122$ & $(6)$ \\
Coefficient of variation (\%) & 2.7 & & 3.9 & \\
\hline
\end{tabular}

Annual mean length exponent was $b=3.050 \pm 0.145$ and did not significantly deviate from $3.0(t=1.200, d f=11, p>0.1)$. Month-to-month variability was low over the one year period ( $\mathrm{CV}=4.80 \%$ ), with values of (b) ranging from 2.887 in November to 3.364 in May. The average (b) depicted isometry in the dry season $t=1.613, \mathrm{df}=5, \mathrm{p}>0.1$ ) but a positive allometry during the rains $(\mathrm{t}=3.072, \mathrm{df}=5, \mathrm{p}<0.05$ ) (Table 2). Moreover, mean (b) for the wet season significantly superseded that of the dry season $\mathrm{t} t=3.139 \mathrm{df}=10$, $p<0.02)$; intraseason variability was low for each season and there was no significant difference between seasons $(F=2.385, \mathrm{p}>0.05)$ (Table 2).

Table 3. Monthly variation in the parameters of the length-weight relationship of female $P$. barbarus in Imo River estuary, Nigeria

\begin{tabular}{|c|c|c|c|c|c|c|}
\hline \multirow[t]{2}{*}{ Months } & \multirow[t]{2}{*}{$N$} & \multicolumn{2}{|c|}{ Total length $(\mathrm{cm})$} & \multicolumn{2}{|c|}{ Regression parameters } & \multirow[t]{2}{*}{$r^{*}$} \\
\hline & & $\mathrm{L}_{\min }$ & $\mathrm{L}_{\max }$ & Intercept (a) & Exponent (b) & \\
\hline April & 13 & 6.0 & 12.6 & 0.0093 & 3.076 & 0.969 \\
\hline May & 33 & 5.9 & 10.5 & 0.0048 & 3.364 & 0.993 \\
\hline June & 32 & 6.6 & 11.8 & 0.0085 & 3.101 & 0.993 \\
\hline July & 36 & 4.7 & 13.3 & 0.0092 & 3.091 & 0.990 \\
\hline August & 66 & 4.7 & 12.6 & 0.0067 & 3.233 & 0.953 \\
\hline September & 75 & 1.3 & 12.2 & 0.0092 & 3.073 & 0.991 \\
\hline October & 71 & 5.3 & 12.2 & 0.0090 & 3.050 & 0.921 \\
\hline November & 68 & 5.1 & 10.7 & 0.0119 & 2.887 & 0.919 \\
\hline December & 37 & 4.6 & 13.6 & 0.0100 & 3.018 & 0.971 \\
\hline January & 35 & 5.0 & 11.1 & 0.0148 & 2.904 & 0.983 \\
\hline February & 79 & 4.7 & 12.4 & 0.0137 & 2.896 & 0.988 \\
\hline March & 57 & 5.9 & 13.5 & 0.0144 & 2.906 & 0.944 \\
\hline
\end{tabular}


The monthly values of (a) and (b) were inversely correlated $(r=-0.978, \mathrm{df}=10$, $\mathrm{p}<0.001$ ) according to a functional equation of the form:

$$
\mathrm{a}=18.3668(\mathrm{~b})^{-6.776}
$$

which accounted for $95.7 \%$ of the variation in the data. No significant correlations were found in the following relationships: $\mathrm{L}_{\min }$ vs (a) $\left(\mathrm{r}=0.016\right.$, df $=10, \mathrm{p}>0.1$ ), $\mathrm{L}_{\max }$ vs (a) $(\mathrm{r}=-0.371, \mathrm{df}=10, \mathrm{p}>0.1), \mathrm{L}_{\min }$ vs $(\mathrm{b})(\mathrm{r}=0.009, \mathrm{df}=10, \mathrm{p}>0.1)$ and $\mathrm{L}_{\max }$ vs $(\mathrm{b})$ $(\mathrm{r}=-0.450, \mathrm{df}=10, \mathrm{p}>0.1)$. The overall length-weight relationship for the female fish was $(r=0.972, d f=620, p<0.001)$ :

$$
\mathrm{W}=0.0111 \mathrm{~L}^{3.013}
$$

This indicates an isometric relationship, with $94.5 \%$ of the variation in body weight being accounted for by changes in length.

There was no significant intersexual variation in values of $(a)$ (paired $t=1.343$, $\mathrm{df}=11, \mathrm{p}>0.1)$ and $(\mathrm{b})$ (paired $\mathrm{t}=0.792, \mathrm{df}=11, \mathrm{p}>0.1$ ). Intersexual divergence in variability was insignificant in respect of $(b)(F=1.593, p>0.05)$ but was significantly higher in males than females in respect of $(a)(F=3.381, p<0.05)$. Since there was no significant intersexual differences in the LW regression parameters of $P$. barbarus, the data were pooled for the general relationship of the form $(r=0.921$, $d f=1.011, p<0.001)$ :

$$
W=0.1533 L^{2.902}
$$

which accounted for $84.8 \%$ of the variance in the data. The exponent of equation 7 depicts an isometric relationship. The only intersexual differences in the LW parameters were in the monthly regimes as depicted by the rank-orders $(n=12)$ of $(a)$ (Spearman rank correlation $r_{s}=0.430, p>0.05$ and $(b)\left(r_{s}=0.413, p>0.05\right)$ (Tables 1 and 3 ).

\section{DISCUSSION}

The overall mean regression exponents in the length-weight relationships of male and female Periophthalmus barbarus were not markedly different from 3.0. Consequently, isometry was maintained in both sexes, thus suggesting indifferent growth in male and female fishes. The population of $P$. barbarus in Imo River estuary is, therefore, a homogenous group with body weight varying approximately with the cube of the total body length (cf. Khan et al., 1991). This was also reflected in the pooled length-weight function for the population (eqn. 7). The results connote that the dynamics of $P$. barbarus population in Imo River estuary can be analysed using various models which assume isometry (Sparre \& Venema, 1992). The ranges of the regression coefficients in the males $(\mathrm{b}=2.676-3.230)$ and females $(\mathrm{b}=2.887-3.364)$ are well within the limits given by Carlander (1969), Royce (1972) and Lagler et al., (1977) for fin fishes. Etim et al. (1996) estimated $\mathrm{b}=2.940$ for the Cross River (Nigeria) population of $P$. barbarus. This is not markedly different from the present overall estimate $(b=2.902)$.

The aseasonality in the values of the length-weight parameters in male P. barbarus indicates that biological phenomena such as foraging pattern, testicular anabolism (reproductive investment) and depletion during spawning have little impact on the length- 
weight functions. In females, mean (a) was higher in the dry season while (b) was higher during the rains. The heightened value of (a) in the dry season is attributable to increase in reproductive investment, and the wet season decline to ovarian depletion at spawning (authors' unpubl. data).

In both sexes of $P$. barbarus, variability in values of (a) exceeded that of (b) probably because in the functional length-weight equation, values of (a) vary with environmental factors whereas (b) tends to remain unchanged during a given life phase (Bagenal \& Tesch, 1978). Caillouet (1993) found a significant negative interspecific correlation between (a) and $L_{\max }$. The lack of significant correlations between $L_{\min }$ and $L_{\max }$ and the length-weight parameters of male $P$. barbarus indicates that the size limits of specimens examined did not influence variations in the magnitudes of (a) and (b).

In the generalized length-weight relationship (eqn. 1), the magnitudes of the parameters can be used to depict the population (or subpopulation) condition factor (Bolger \& Connolly, 1989). In a case of isometry in a LWR (i.e. $b=3.0$ ), the proportionality constant (a) can be interpreted as condition factor $(\mathrm{K})$ when multiplied by 100 (Pauly, 1993). The LW functions of both sexes of P. barbarus conform to this criterion. Table 4 shows the monthly trends in the condition indices of male and female fishes. Male condition ranged from $K_{\min }=0.65$ (May, November) to $K_{\max }=2.51$ (March), with a gross average of $K=1.19 \pm 0.57$. The latter did not significantly deviate from the expected value of 1.0 for fish in good body condition $(t=1.155, \mathrm{df}=11, \mathrm{p}>0.1)$. Average condition indices for the dry $(K=1.32 \pm 0.69)$ and wet $(K=1.06 \pm 0.44)$ seasons were not significantly different $(t=0.710, d f=10, p>0.05)$. Similarly, intraseason variability for the dry $(\mathrm{CV}=52.3 \%)$ and wet $(\mathrm{CV}=41.5 \%)$ seasons were not significantly different $(\mathrm{F}=2.459$, $\mathrm{p}>0.05$ ).

Overall mean condition of female $P$. barbarus was $\mathrm{K}=1.01 \pm 0.31$ and did not significantly deviate from $1.0(t=0.112, \mathrm{df}=11, \mathrm{p}>0.1)$; it varied from $\mathrm{K}_{\min }=0.48$ during the onset of the rains (May) to $K_{\max }=1.48$ during the peak of the dry season (January). Average condition for the dry season $(K=1.24 \pm 0.23)$ significantly exceeded the wet season

Table 4. Monthly variation in the condition factor $(K)$ of male and female $P$. barbarus in Imo River estuary, Nigeria

\begin{tabular}{|c|c|c|}
\hline \multirow[t]{2}{*}{ Month } & \multicolumn{2}{|c|}{ Condition factor $(\mathrm{K})$} \\
\hline & Male & Female \\
\hline April & 0.89 & 0.93 \\
\hline May & 0.65 & 0.48 \\
\hline June & 0.66 & 0.85 \\
\hline July & 1.25 & 0.92 \\
\hline August & 1.03 & 0.67 \\
\hline September & 0.93 & 0.92 \\
\hline October & 1.81 & 0.90 \\
\hline November & 0.65 & 1.19 \\
\hline December & 0.84 & 1.00 \\
\hline January & 1.60 & 1.48 \\
\hline February & 1.43 & 1.37 \\
\hline March & 2.51 & 1.44 \\
\hline
\end{tabular}


value $(\mathrm{K}=0.79 \pm 0.1)(\mathrm{t}=3.445, \mathrm{df}=10, \mathrm{p}<0.01)$ due to increased dry season reproductive investment. During the wet season most of the females were in their post-spawning or recovery phases of ovarian cycle typified by low body condition (authors' unpublished data). Intraseason variability in body condition for the dry $(\mathrm{CV}=18.6 \%)$ and wet $(\mathrm{CV}=22.8 \%)$ seasons were not significantly different $(\mathrm{F}=1.633, \mathrm{p}>0.05)$.

Male and female $P$. barbarus were not significantly different in their body condition (paired $t=1.342, \mathrm{df}=11, \mathrm{p}>0.1$ ) but intra-annual variability was significantly higher in males $(\mathrm{CV}=47.9 \%)$ than females $(\mathrm{CV}=30.7 \%)(\mathrm{F}=3.381, \mathrm{p}<0.05)$.

The higher intra-annual variability in values of (a) and condition factor $(\mathrm{K})$ of male $P$. barbarus vis a vis the female could be due to the fact that the former sex is more susceptible to fluctuations in environmental conditions. The reason for this trend is uncertain but could be linked to males' greater mobility over the mudflats while foraging and protecting the burrows.

\section{LITERATURE CITED}

Bagenal, T. B. \& Tesch, F. W., 1978. Age and growth. In: Fish production in fresh waters. Ed. by T. B. Bagenal. Blackwell, Oxford, 101-136.

Becker, C. D., 1972. Food and growth parameters of juvenile chinoock salmon, Oncorhychus tshawyscha, in central Columbia River. - Fish. Bull. U.S. 71, 387-400.

Bolger, T. \& Connolly, P. L., 1989. The selection of suitable indices for the measurement and analysis of fish condition.- J. Fish Biol., 34, 171-182.

Caillouet, C. W. Jr., 1993. On comparing groups of fishes based on length-weight relationships. Naga $16,30-31$

Carlander, K., 1969. Handbook of fresh water fishery biology. Iowa State University Press, Ames, Iowa, 1, 1-752.

Egborge, A. B. M., 1993. Biodiversity of aquatic fauna of Nigeria. Natural Resources Conservation Council, Abuja, Nigeria, 173 pp.

Enplan Group, 1974. Imo River Basin Pre-feasibility Report. Fed. Min. of Agric., Lagos, Nigeria, 2. Pages not consecutively numbered.

Etim, L. Brey, T. \& Arntz, W., 1996. A seminal study of the dynamics of a mudskipper Periophthalmus papilio population in the Cross River system, Nigeria. - Neth. J. aquat. Ecol, 30, 41-48.

Khan, M. S., Ambak, M. A., Ang, K. J. \& Moshin, A. K. M., 1991. Length-weight relationship and relative condition of a Malaysian fresh water catfish, Mystus nemurus Cuvier \& Valenciennes, in Chenderoh Reservoir. - Aquacult. Fish. Mgmt, 22, 373-376.

Lagler, K. F., Bardach, J. E., Miller, R. R. \& Passino, D. R. M., 1977. Ichthyology. Wiley, New York, $506 \mathrm{pp}$.

Lewontin, R. C., 1966. On the measurement of relative variability. - Syst. Zool. 15, 141-142.

Moreau, J., Bambino, C. \& Pauly, D., 1986. Indices of overall performance of 100 Tilapia (Cichlidae) population. In: The First Asian Fisheries Forum. Ed. by J. L. Maclean, L. B. Dizon \& L. V. Hosillos. Asian Fisheries Society, Manila, 201-206.

Pauly, D., 1993. Editorial: Fishbyte section. - Naga 16, 26.

Royce, W. F., 1972. Introduction to the fishery sciences. Acad. Press, New York, $351 \mathrm{pp}$.

Sparre, P. \& Venema, S. C., 1992. Introduction to tropical fish stock assessment. Part 1: Nabyak. FAO Fish. tech. Pap. 306. 1. Rev. 1. 1-376.

Tyler, A. V. \& Gallucci, V. F., 1980. Dynamics of fished stocks. In: Fisheries management. Ed. by R. Lackey \& L. A. Nielsen. Blackwell, Oxford, 111-147. 